\section{Self-disclosure of HIV diagnosis to sexual partners by heterosexual and bisexual men: a challenge for HIV/AIDS care and prevention}

\author{
A revelação da soropositividade por homens \\ bissexuais e heterossexuais para parceiros \\ sexuais: um desafio para o cuidado \\ e a prevenção do HIV/AIDS
}

\footnotetext{
1 Instituto de Psicologia, Universidade de São Paulo, São Paulo, Brasil.

2 Faculdade de Medicina, Universidade de São Paulo, São Paulo, Brasil.

3 Programa de DST/AIDS,

Secretaria de Saúde de São Paulo, São Paulo, Brasil.

Correspondence

V. Paiva

Instituto de Psicologia, Universidade de São Paulo. Av. Prof. Mello Moraes 1721, São Paulo, SP 05508-900, Brasil.

veroca@usp.br
}

\begin{abstract}
This study investigated the disclosure of HIVpositive serostatus to sexual partners by heterosexual and bisexual men, selected in centers for HIVIAIDS care. In 250 interviews, we investigated disclosure of serostatus to partners, correlating disclosure to characteristics of relationships. The focus group further explored barriers to maintenancelestablishment of partnerships and their association with disclosure and condom use. Fear of rejection led to isolation and distress, thus hindering disclosure to current and new partners. Disclosure requires trust and was more frequent to steady partners, to partners who were HIV-positive themselves, to female partners, and by heterosexuals, occurring less frequently with commercial sex workers. Most interviewees reported consistent condom use. Unprotected sex was more frequent with seropositive partners. Suggestions to enhance comprehensive care for HIV-positive men included stigma management, group activities, and human rights-based approaches involving professional education in care for sexual health, disclosure, and care of "persons living with HIV".
\end{abstract}

Sexuality; HIV; Acquired Immunodeficiency Syndrome
Vera Paiva 1

Aluisio C. Segurado 2

Elvira Maria Ventura Filipe 3

\section{Introduction}

Disclosure of HIV-positive serostatus has been defined as a process of communicating potentially stigmatizing information that had previously been kept hidden in order to increase one's psychological well-being, and in the case of disclosure to sexual partners, to preserve the quality of relationships. Disclosure is thus not a simple act. It involves careful consideration of "to whom" and "when" and depends on preparation and a personal decision.

When people discover they are HIV-infected, many isolate themselves due to fear of rejection and abandonment, when they think of disclosing their serostatus $1,2,3,4$. Studies on the issue with samples of persons living with HIV in countries of the Americas, Europe, and Asia with access to treatment have indicated that disclosing one's HIV diagnosis decreases stress and isolation, expands social support, and favors adaptation to medication intake and negotiation of safer sex in various inter-subjective contexts, with an impact on controlling the spread of the epidemic. Meanwhile, the combined stigmas associated with HIV (homophobia, sexism, and racism) increase the difficulties in self-disclosure 5,6. Persons also tend to disclose their status more readily with steady and regular sexual partners, in the context of longer-lasting and marital relations, than to persons with whom they have casual encounters; for 
people living with HIV, having sex without disclosing one's diagnosis to partners is common 7.

As described by Klitzman \& Bayer 8 in a study aimed at understanding the dynamics of disclosure of HIV diagnosis to partners, family members, friends, and coworkers in New York City, various codes for indirectly communicating one's positive serostatus are used, such as leaving medication in plain view in the living room and educating partners on the need for people in general to protect themselves with condoms; such strategies are more common among homosexual men, among whom HIV prevalence is often high. In their study, those that adopted this way of disclosing their diagnosis felt that veiled messages met the moral imperative of communicating seropositive status; others considered such approaches morally unacceptable, a half-lie. In contexts of anonymous or casual sex (heterosexual or homosexual), silencing on seropositive status was viewed as more acceptable; speaking about infection in these situations was perceived as anti-erotic. On the other hand, more lasting relationships assume or require trust in order to be establish, and non-disclosure could perpetuate mistrust; meanwhile, disclosure to one partner could help build the confidence what would tend to stimulate disclosure to others.

The few Brazilian studies on this theme that include men discuss disclosure of the diagnosis "to" persons with HIV, rarely "by" persons living with HIV to significant others, even though they recognize that this question has an important impact on health and quality of life 9,10.

This article describes the disclosure of HIV diagnosis in the context of the affective and sexual lives of heterosexual and bisexual men living with HIV and discusses how health services could contribute to this process.

\section{Method}

The study was conducted in two stages, according to a design that has been presented elsewhere $6,11,12,13$. Briefly, in the first stage, a consecutive sample of 250 men, patients followed at two referral centers for HIV/AIDS care in São Paulo, Brazil, were invited to participate in a questionnaire-based interview containing open and closed questions on socio-demographic data, information related to HIV infection, experiences with discrimination and support, and reports on their affective and sexual lives. The principal outcome for this study was the patient's report of having disclosed his seropositive status to sexual partners (men and women). The study included patients in good health condition, 18 years old or older, and who reported having sexual contact with women.

Considering that experiences with disclosure of seropositive status can occur differently in distinct groups of men living with HIV, a disaggregated data analysis was conducted according to self-reported skin color and sexual behavior. As proposed in studies on the impact of racism in healthcare in Brazil 14, for the "skin color" variable, "blacks" were defined as the sum of self-identified "blacks" and "browns", and "nonblacks" were defined as the sum of whites, Asiandescendents, and indigenous. Based on reported sexual practices, bisexual was defined as a man who reported having had sexual relations with another man anytime in his life, besides sexual relations with women.

In addition, we aimed at characterizing the sexual life of the men included in the study, on the assumption that disclosure of seropositive status could be associated with variables related to their sexual partnerships. We thus asked interviewees to list the persons with whom they had had sexual relations in the six months prior to the interview. Next, for each listed partner, the interviewees specified: serostatus (HIV-positive, HIV-negative, or unknown); whether the partner (male or female) knew that the interviewee was seropositive; whether he used condoms with him/her (yes, no); whether they constituted "steady partnerships" (girlfriend/boyfriend, spouse, cohabiting), concurrent or not "regular partners" (casual dates, lovers, affairs, friends with whom they had sex), or "de programa" (a Brazilian category for casual sex exchanged for money or favors). For purposes of analysis, we defined "main partner" as the partner (female or male) listed first by the interviewee.

For comparison of the target variables (extracted from the answers to the questionnaire) between the various groups (blacks, non-blacks; homosexuals, bisexuals), we used the chi-square test using SPSS 13.0 (SPSS Inc., Chicago, USA).

For the second stage of the study, we invited all the interviewees who at the end of the interview had shown interest in participating in group activities. The objective of the first group session was to present the interviewees with the preliminary analysis of the interviews from the first stage and to discuss it with the participants, as well as to raise themes for four additional sessions related to living with HIV/AIDS. The four discussions were conducted with the interviewees in one of the two HIV/AIDS services. The chosen themes included: (1) the desire to have children, and the possibility of doing so; (2) difficulties in getting and keeping a job; (3) prejudice; (4) difficulties in affective and sexual relations or in 
starting a new relationship, a theme focused on this current study. The number of participants in the four sessions organized in a focus group format varied from 14 to 18 men. All the meetings were coordinated by a psychologist, assisted by two members of the research team, and lasted approximately two hours each, were taped and transcribed.

In this article we analyze the recordings of the $4^{\text {th }}$ session group, in which the issue of disclosure of HIV diagnosis emerged, and in which 14 men participated. The analysis sought to explore lines of meaning, practical significance, values and feelings related to disclosure of the diagnosis to sexual partners. The interviewees' responses to the open questions on their affective-sexual life after disclosing their seropositive status were also analyzed, after the responses to the open questions were categorized by two evaluators 15 .

The study design and informed consent process guaranteed confidentiality in data processing and were approved by the Institutional Review Boards of the two participating centers.

\section{Results}

A more in-depth understanding of adaption process in the affective and sexual life as a person living with HIV carriers is essential for contextualizing the dilemmas involved in disclosing their diagnosis to sexual partners. We found important differences in this experience when comparing bisexual and heterosexual men.

\section{Study subjects' characteristics}

Table 1 shows the distribution of study subjects by age, income, work situation, schooling, marital status, number of children, and religion. Among the interviewees, 58\% identified themselves as white and $0.8 \%$ as either Asian-descendant or indigenous (i.e., $58.8 \%$ were classified as "non-black"); 14\% identified themselves as black and $27 \%$ as brown (i.e., $41 \%$ were classified as "black"). Ninety-five men (38\%) stated having had sexual relations with other men at some time in their lives, and for purposes of analysis they were considered bisexual. The mean time since the last homosexual contact was 4 years (median 2 years). There was no difference in the proportion of bisexuals between blacks and non-blacks. As for the socio-demographic variables, the only significant difference between blacks and nonblacks was in schooling $(\mathrm{p}=0.00)$.

The comparison between heterosexuals and bisexuals showed differences. Proportionally more bisexual men had reached the university
( $\mathrm{p}=0.01)$, while proportionally more heterosexual men were married and had children $(\mathrm{p}=$ 0.00). Among heterosexuals, there were likely to be unemployed and fewer had formal jobs (with signed work papers).

As for HIV infection, time since diagnosis varied from 1 month to 17 years (mean 5.7 years), and $92 \%$ of the interviewees reported taking antiretrovirals. As discussed previously 11, the most common reason for having been tested for HIV was having HIV-related symptoms (42\%), and the majority (55\%) did not expect a positive HIV test result. Sexual transmission was reported as the most common route of infection, and $11 \%$ mentioned injecting drug use. An important proportion of interviewees (16\%) did not know they had been tested when they received the result, a situation that was more frequent among heterosexuals (19.7\%) as compared to bisexuals (9.7\%).

As for the impact of the beginning of antiretroviral treatment, $16 \%$ reported an increase in the frequency of situations involving discrimination or tension in hiding their status, fearing that the number of medical consultations and constantly medication intake would reveal their HIVpositive status. A high proportion of interviewees (88.5\%) stated that they practiced some religion, with Catholicism as the most common. The majority had children, and $13 \%$ of the children had been born after the interviewees received their HIV diagnosis, an issue discussed more deeply in another article 12 .

\section{Sexuality and its relationship to disclosure of diagnosis}

Table 2 summarizes the data for all the women and men that were listed by the sexually active interviewees as their sexual partners in the six months prior to the interview and about whom the interviewees provided data. These included spouses and steady girlfriends/boyfriends $(70 \%$ had been partners for more than six months at the time of the interview), as well as consecutive or concurrent girlfriends/boyfriends and affairs over the course of 6 months. Importantly, the partners (men or women) that were paid for sex - "programa" - (32\% of the sexual partners) were the persons to whom the interviewees least frequently disclosed their seropositive status, in contrast to disclosure to spouses and boyfriends / girlfriends (69\% of the partners that knew). These characteristics, discussed next, were well-represented in relations with the persons chosen as the "main partner". 
Socio-demographic profile of black and non-black and bisexual and heterosexual interviewees.

\begin{tabular}{|c|c|c|c|c|}
\hline Characteristics & $\begin{array}{c}\text { Non-black } \\
(\mathrm{N}=147) \\
n(\%)\end{array}$ & $\begin{array}{c}\text { Black } \\
(\mathrm{N}=103) \\
n(\%)\end{array}$ & $\begin{array}{l}\text { Heterosexual } \\
\begin{array}{c}(\mathrm{N}=155) \\
\mathrm{n}(\%)\end{array}\end{array}$ & $\begin{array}{c}\text { Bisexual } \\
(\mathrm{N}=95) \\
n(\%)\end{array}$ \\
\hline \multicolumn{5}{|l|}{ Age (years) } \\
\hline$\leq 24$ & $4(2.7)$ & $5(4.9)$ & $4(2.6)$ & $5(5.3)$ \\
\hline $25-34$ & $43(29.3)$ & $27(26.2)$ & $43(27.7)$ & $27(28.4)$ \\
\hline $35-45$ & $57(38.8)$ & $41(39.8)$ & $62(40.0)$ & $36(37.9)$ \\
\hline $45-74$ & $43(29.3)$ & $30(29.1)$ & $46(29.7)$ & $27(28.4)$ \\
\hline \multicolumn{5}{|l|}{ Schooling * } \\
\hline None & $3(2.0)$ & $4(3.9)$ & $6(3.9)$ & $1(1.1)$ \\
\hline Incomplete primary & $29(19.7)$ & $42(40.8)$ & $50(32.3)$ & $21(22.1)$ \\
\hline Complete primary/secondary & $71(48.3)$ & $45(43.7)$ & $74(47.7)$ & $42(44.2)$ \\
\hline University (> 12 years of schooling) & $44(29.9)$ & $12(11.7)$ & $25(16.1)$ & $31(32.6)$ \\
\hline \multicolumn{5}{|c|}{ Monthly income per household member (Reais) ** } \\
\hline None & $6(4.2)$ & $3(3.1)$ & $6(4.0)$ & $3(3.3)$ \\
\hline$\leq 150.00$ & $18(12.6)$ & $15(15.5)$ & $24(16.1)$ & $9(9.9)$ \\
\hline $151.00-300.00$ & $30(21.0)$ & $24(24.7)$ & $39(26.2)$ & $15(16.5)$ \\
\hline $301.00-600.00$ & $30(21.0)$ & $30(30.9)$ & $36(24.2)$ & $(26.4)$ \\
\hline$>601.00$ & $59(41.3)$ & $25(25.8)$ & $44(29.5)$ & $40(44.0)$ \\
\hline \multicolumn{5}{|l|}{ Employment status } \\
\hline Employed & $46(31.7)$ & $31(30.1)$ & $43(27.9)$ & $34(36.2)$ \\
\hline Self-employed & $38(26.2)$ & $17(16.5)$ & $30(19.5)$ & $25(26.6)$ \\
\hline Odd jobs & $8(5.5)$ & $11(10.7)$ & $16(10.4)$ & $3(3.2)$ \\
\hline Unemployed & $19(13.1)$ & $17(16.5)$ & $27(17.5)$ & $9(9.6)$ \\
\hline Retired/On leave & $24(23.4)$ & $27(26.2)$ & $38(24.7)$ & $23(24.5)$ \\
\hline \multicolumn{5}{|l|}{ Marital status *** } \\
\hline Single & $65(44.2)$ & $47(46.1)$ & $48(31.2)$ & $64(67.4)$ \\
\hline Married/Cohabiting & $62(42.2)$ & $39(38.2)$ & $76(49.4)$ & $25(26.3)$ \\
\hline Separated/Divorced & $14(9.5)$ & $10(9.8)$ & $21(13.6)$ & $3(3.2)$ \\
\hline Widow(er) & $6(4.1)$ & $6(5.9)$ & $9(5.8)$ & $3(3.2)$ \\
\hline \multicolumn{5}{|l|}{ 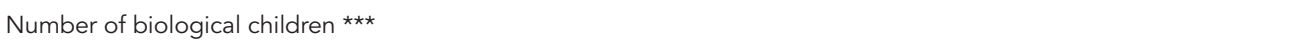 } \\
\hline None & $68(46.3)$ & $53(51.5)$ & $58(37.4)$ & $63(66.3)$ \\
\hline 1 & $31(21.1)$ & $24(23.3)$ & $40(25.8)$ & $15(15.8)$ \\
\hline 2 & $32(21.8)$ & $10(9.7)$ & $28(18.1)$ & $14(14.7)$ \\
\hline$\geq 3$ & $16(10.9)$ & $16(15.5)$ & $29(18.7)$ & $3(3.2)$ \\
\hline \multicolumn{5}{|l|}{ Religion } \\
\hline Catholic & $79(54.1)$ & $45(43.7)$ & 79 (51.3) & $45(47.4)$ \\
\hline Evangelical/Protestant & $23(15.8)$ & $25(24.3)$ & $32(20.8)$ & $16(16.8)$ \\
\hline Spiritist & $15(10.3)$ & $11(10.7)$ & $13(8.4)$ & $13(13.7)$ \\
\hline Buddhist/Jewish/Other & $11(7.5)$ & $6(5.8)$ & $10(6.5)$ & $7(7.4)$ \\
\hline African Brazilian & $1(0.7)$ & $4(3.9)$ & $1(0.1)$ & $4(4.2)$ \\
\hline None & $17(11.6)$ & $12(11.7)$ & $19(12.3)$ & $10(10.5)$ \\
\hline
\end{tabular}

Note: the total number is not always the same, due to missing answers for each variable.

* Significance of the difference between non-blacks and blacks for schooling $(p=0.000)$; between heterosexuals and bisexuals for schooling $(p=0.011)$;

** 1 monthly minimum wage $=\mathrm{R} \$ 200.00$;

$* \star \star$ Significance of the difference between heterosexuals and bisexual for marital status $(p=0.000)$ and number of children $(p=0.000)$ 
Distribution of women and men listed as sexual partners in the 6 months prior to the interview according to relationship, serostatus, and disclosure of serostatus by the interviewee.

\begin{tabular}{|c|c|c|c|c|c|c|c|c|}
\hline \multirow[t]{2}{*}{ Relationship } & \multicolumn{4}{|c|}{ Women } & \multicolumn{4}{|c|}{ Men } \\
\hline & $\begin{array}{l}\text { Spouse/ } \\
\text { Steady } \\
\text { girlfriend }\end{array}$ & $\begin{array}{l}\text { Affair/ } \\
\text { Date }\end{array}$ & $\begin{array}{c}\text { "Programa" } \\
\text { (paid sex) }\end{array}$ & Total & $\begin{array}{l}\text { Spouse/ } \\
\text { Steady } \\
\text { boyfriend }\end{array}$ & $\begin{array}{l}\text { Affair/ } \\
\text { Date }\end{array}$ & Trick & Total \\
\hline \multicolumn{9}{|c|}{ Partner's serostatus } \\
\hline $\mathrm{HIV+}$ & 37 & 13 & 12 & 62 & 13 & 4 & 3 & 20 \\
\hline HIV- & 88 & 27 & 16 & 131 & 8 & 11 & 4 & 23 \\
\hline Doesn't know & 11 & 31 & 59 & 101 & 2 & 16 & 30 & 48 \\
\hline Total (\%) & $136(46.3)$ & $71(24.1)$ & $87(29.6)$ & $294(100.0)$ & $23(25.3)$ & $31(34.0)$ & $37(40.7)$ & $91(100.0)$ \\
\hline \multicolumn{9}{|c|}{ Did he or she know? } \\
\hline Yes & 117 & 31 & 13 & 161 & 20 & 9 & 9 & 38 \\
\hline No & 11 & 36 & 72 & 119 & 2 & 21 & 28 & 51 \\
\hline Total (\%) & $128(45.7)$ & $67(23.9)$ & 85 (30.4) & $280(100.0)$ & $22(24.7)$ & $30(33.7)$ & $37(41.6)$ & 89 (100.0) \\
\hline
\end{tabular}

Note: the total number is not always the same, due to missing answers for each variable.

\section{Disclosure and condom use with the main partner}

We found no differences between interviewees in the disclosure of seropositive status to the main partner when comparing different age groups, schooling, religion, or blacks and non-blacks (data not shown).

Comparing those that disclosed their serostatus to the main partner versus those that did not (Table 3), the proportion of interviewees that disclosed their diagnosis was higher in the case of female partners or partners that were also HIVpositive. There was also a significant difference in the frequency of disclosure as a function of the type of relationship with the partner (more frequent with steady partners) and condom use during anal sex.

Importantly, seven men failed to disclose their HIV-positive status and were not using condoms: two men who had unprotected vaginal sex with "steady [female] partners", two with "regulars" (lovers), and one with a "programa" (in this case a female sex worker); two men exposed female sex workers to infection by having anal sex with them without condoms. Meanwhile, the proportion of safer sex with the main partner was quite high, both for vaginal sex $(83.1 \%$ always used condoms) and anal sex ( $42 \%$ always used condoms and 45\% did not have anal sex).

Difficulties in disclosing the diagnosis to male and female partners and condom use were explored in the open questions, the source of the quotes below. Twenty male interviewees reported varying degrees of difficulty in starting a new relationship because of the need to reveal their HIV status.

"I feel better telling the truth. Last week I met a woman, and when I was putting the condom on she asked why. I explained everything and she accepted me" (Participant U).

Corroborating observations by Klitzman \& Bayer 8 , most of our interviewees adopted the moral imperative of revealing their diagnosis, on grounds that it was "unethical to deceive", words that were frequently repeated in the interviews. Meanwhile, some preferred to strengthen the emotional link first and reveal one's diagnosis later.

"I would only tell [about my diagnosis] if the relationship became serious, but I wouldn't put her life in jeopardy" (Participant W).

One interviewee had a girlfriend when he received his HIV diagnosis. He left her without giving her any explanation after discovering that she was HIV-negative. Many of the study subjects acknowledge prejudice in their own experience, associating it with "ignorance".

"When you don't know, everything's beautiful. Later things change, there's the barrier... of contamination... lack of dialogue... secrets... fear. I was prejudiced myself. Even if she were the most beautiful women in the world, I'd split" (ParticipantV).

One of the 72 men among those that did not feel bound to disclose his diagnosis to sex workers thought it was very difficult to talk about the issue and also did not trust in persons living with HIV. 
Disclosure of diagnosis according to relationship (men and women), serological status of the main partner, and condom use.

\begin{tabular}{|c|c|c|c|c|c|c|}
\hline \multirow[t]{2}{*}{ Characteristics } & \multicolumn{2}{|c|}{ Disclosed } & \multicolumn{2}{|c|}{ Did not disclose } & \multicolumn{2}{|c|}{ Total } \\
\hline & $\mathrm{n}$ & $\%$ & $\mathrm{n}$ & $\%$ & $\mathbf{N}$ & $\%$ \\
\hline \multicolumn{7}{|l|}{ Women * } \\
\hline Steady & 105 & 92.9 & 8 & 7.1 & 113 & 100.0 \\
\hline Regular & 11 & 44.0 & 14 & 56.0 & 25 & 100.0 \\
\hline Date & 2 & 10.0 & 18 & 90.0 & 20 & 100.0 \\
\hline Sub-total & 118 & 74.7 & 40 & 25.3 & 158 & 100.0 \\
\hline \multicolumn{7}{|l|}{ Men * } \\
\hline Steady & 15 & 88.2 & 2 & 11.8 & 17 & 100.0 \\
\hline Regular & 5 & 33.3 & 10 & 66.7 & 15 & 100.0 \\
\hline Date & 2 & 33.3 & 4 & 66.7 & 6 & 100.0 \\
\hline Sub-total & 22 & 57.9 & 16 & 42.1 & 38 & 100.0 \\
\hline \multicolumn{7}{|l|}{ Partner's serostatus } \\
\hline $\mathrm{HIV+}$ & 51 & 98.1 & 1 & 1.9 & 52 & 100.0 \\
\hline HIV- & 76 & 79.2 & 20 & 20.8 & 96 & 100.0 \\
\hline Doesn't know & 13 & 27.1 & 35 & 72.9 & 48 & 100.0 \\
\hline Sub-total & 140 & 71.4 & 56 & 28.6 & 196 & 100.0 \\
\hline \multicolumn{7}{|l|}{ Condom use } \\
\hline \multicolumn{7}{|l|}{ Vaginal sex } \\
\hline Always & 94 & 73.4 & 34 & 26.6 & 128 & 100.0 \\
\hline Sometimes & 13 & 86.7 & 2 & 13.3 & 15 & 100.0 \\
\hline Never & 8 & 72.7 & 3 & 27.3 & 11 & 100.0 \\
\hline Sub-total & 115 & 74.7 & 39 & 25.3 & 154 & 100.0 \\
\hline \multicolumn{7}{|l|}{ Anal sex ** } \\
\hline Always & 50 & 61.7 & 31 & 38.3 & 81 & 100.0 \\
\hline Sometimes & 5 & 83.3 & 1 & 16.7 & 6 & 100.0 \\
\hline Never & 17 & 94.4 & 1 & 5.6 & 18 & 100.0 \\
\hline Doesn't apply & 66 & 75.9 & 21 & 24.1 & 87 & 100.0 \\
\hline Sub-total & 138 & 71.9 & 54 & 28.1 & 192 & 100.0 \\
\hline
\end{tabular}

Note: the total number is not always the same, due to missing answers for each variable.

* Differences $\mathrm{p}<0.00$

** Differences $p=0.02$.

“HIV-positive people don't have lasting relationships. The person gets uptight and can't stick to one partner, and ends up playing around" (Participant X).

In contexts marked by stigma and prejudice, failing to reveal one's diagnosis and only incorporating condom use does not always solve the difficulty, frequently raises suspicion of something unacceptable, and triggers stigma rather than the partner's complicity in prevention: "If you mention condoms, [the other person reacts], 'What's up, do you think I'm sick?"' (Participant Y).

Disclosure, as Table 3 shows, tends to be more common to HIV-positive male and female partners $(98 \%$ of the interviewees revealed their diagnosis to HIV-positive main partners as compared to $79 \%$ of HIV-negative partners), a tendency that can be understood based on the fear of prejudice and rejection expressed in the responses by the vast majority of those that elaborated on the answers in the open question on this issue.

"A lot of people are ignorant, they lack information, they're afraid because it involves prejudice. I have a new [female] partner now. But she had to give up her family. My own mother took it on herself to tell..." (Participant Z).

\section{Discussion disclosure to sexual partners in a group session}

Difficulties with disclosure to sexual partners were discussed in focus group session 4 , which 
included 14 men (married and single, bisexual and heterosexual, of various ages, religions, educational levels, blacks and non-blacks, and employed, unemployed, and retired).

The need to "trust in order to reveal one's diagnosis", with fear of abandonment and rejection, appeared constantly in the debate. We quote several passages below to illustrate the wealth of this group session experience, positively assessed by participants (the letters refer to different participants).

"It's happened with me twice, when I told, the person didn't want to go out with me anymore. Some people think you're promiscuous just because you're HIV-positive. That's prejudice, and I don't even go out anymore, to avoid getting hurt" (Participant A).

"Some people think that if you're HIV-positive you can't have sex" (Participant B).

"I'm still doing fine sexually. I don't have any problems even with HIV, or with taking my meds. For me, it only gets tough if I get [emotionally] involved, because if I'm in love, then I'm going to have to tell. That's when the fear of rejection comes in, when you realize you're in love, and you think, 'I'm going to be rejected because of it!'” (Participant $\mathrm{C}$ ).

Disrespect for the right to an active sexual and reproductive life is part of the social scenario marking the lives of persons living with HIV 12 , but experiences in talking about this issue with health professionals in specialized services were quite rare according to participants. In the group discussion setting, they shared various ways of coping with their difficulties in this area, already reported by many interviewees.

"I was going out with a person, and the time came when she wanted to have sex without a condom. I said no. She asked why. I said I wanted prevention from sexually transmissible diseases. She said she didn't have anything. I asked, 'Are you sure I am not?' I broke off the relationship. I didn't want to tell [disclose]" (Participant A).

"To avoid the problem of whether to tell, some people date through the classified ads. 'Carriers looking for carriers. The problem is that people don't fall in love through the classifieds. It's difficult to tell the person. I've had relations where I told, and it was cool, but there was one person I was very involved with, and the day I was going to tell I was trembling. She was also very involved, but she didn't know how to deal with it. So I felt bad, and I ended up dropping out of the relationship" (Participant B).

"I'm in a relationship, my woman has HIV, and I don't use condoms. It's like eating candy in the wrapper" (Participant $\mathrm{C}$ ).

"My wife is not HIV-positive. At first she was afraid that I'd transmit [the virus] to her. Later we went to the doctor together, to talk. The doctor talked to her and explained things. So lately I haven't been having sex with her. She was getting really uptight, wanting me to get [the sex] over with quickly, for fear that the condom would burst" (Participant B).

"My problem is basically like his. I've been married for 30 years, and it used to be normal, but then it began, when we were going to have sex, and I always saw that fear in her, it wasn't something that we wanted spontaneously, it caused fear, and we drifted farther and farther apart. We're still together, but we don't do anything anymore. So I'm forced to play around. And then I use condoms. It's bad, I don't like it. But better with condoms than nothing" (Participant E).

"For me, it's not over yet. It's in the cooling-off phase, but without letting it cool off, right? She's HIV-positive. But I think this cooling-off phase of ours in the last two years was due more to having a new baby. He's almost three years old now" (Participant F).

"This condom business, in the beginning it made me mad, I didn't want anything to do with condoms. I took a dim view of condoms. The doctor explained that [unprotected sex] increased the amount of virus, the viral resistance, and that you could catch a virus that would knock you out once and for all, no way around it. And I began to use them, but I didn't know how. And the doctor explained how to do it. She said, "The first thing you need to do to use condoms normally is to practice alone. You put the condom on and masturbate, and after you've done that two or three times, you're already using the condom okay, and it's not going to get in the way anymore.' So you get used to it, after three times, you're ready. And it really is protection, not just for the person that's having sex with you, but for you as well. There are some diseases that don't give you a break, like hepatitis $C$ which is a goodbye call - if you catch it, it's all over" (Participant G).

"In my case, I didn't even try [to use a female condom with my wife], because I've known the woman for 30 years. She's a tough character, you know?" (Participant E).

"This condom business varies, right? In the beginning it's difficult, it bothers you and all. But when you begin to practice, the time comes when it's automatic. So my wife, my son's mother, I brought her here [to the clinic], she did the tests, and we were having sex with condoms. But you always think, 'Are you sure it didn't leak, what about that game we were playing, and I don't know what all...'I never resisted using condoms, and we never had any problem in bed or with not wanting [sex], because we were both very conscientious. I even brought female condoms, which we tried once, but 
they're very uncomfortable, so we preferred for me to use the condom. I think it's very important to include the family [into the health service], the person that's in bed with you. Because for whoever is on the outside, the word AIDS is really scary" (Participant B).

"The other person also has to care for herself or himself. Otherwise you go to bed with the other person feeling like the 'Hiroshima bomb', and it doesn't work" (Participant A).

\section{Discussion}

Answers to the questionnaire-based interview and the above-mentioned debate among male interviewees corroborated the literature that describes fear of the stigma and discrimination associated with HIV as one of the principal factors hindering disclosure of HIV-positive status to future and current sexual partners. The results are consistent with authors that propose expanding care for persons living with HIV beyond management of the infection itself to include comprehensive care that approaches their sexuality and issues like disclosure.

Analogously to the observations by Klitzman \& Bayer ${ }^{8}$, we observed the need for individuals to "gain trust" in order to disclose their diagnosis, besides the search for relationships with HIV-positive partners, which some of the interviewees considered the only morally acceptable sexual relationship. Non-disclosure of their HIV diagnosis was also reported as more acceptable in the case of anonymous or paid sex partners.

It is relevant that the vast majority of the interviewees used condoms during sexual relations. Meanwhile, many male and female partners, even when they were HIV-negative and aware of the partner's diagnosis, accepted or even proposed having sex without condoms, because "love is blind" as one bisexual man reported, or because "sometimes [the woman] seems silly, pretending I don't have [HIV]". As observed in other studies with men 16,17, sexual activity in the context of conjugality or a relationship involved different practices as compared to those in the context of relations with lovers or affairs (regular but not conjugal partners), further differing from practices with partners paid for "programa" (exchanged for money or favors), with repercussions on the disclosure process. Again, one observes that unprotected sex occurs more frequently with other persons also living with HIV as compared to sex with partners of unknown serostatus or whom one knows to be HIV-negative 17,18.

Moreover, as in other recent studies in the United States 17 , many participants reported that in addition to "serosorting" (choosing persons with the same serostatus), simply stopping sexual relations with their spouses, or failing to seek new partners, because they found it difficult to cope with the moral imperative of revealing their diagnosis or were not confident that they would be capable of protecting their partners - incapable of hiding what they considered a central aspect of their identity, or of believing that condoms would protect their partners from infection or both from re-infection.

These findings are consistent with the results of studies in mixed samples (women and men, heterosexual and bisexual) in the context of access to treatment. As with our findings, disclosure rates of HIV-positive status to partners as described in the literature vary from $67 \%$ to $88 \%$ 5 and are higher in the case of longer-term and HIV-positive partners; the rates also tend to be lower in the case of casual partners 7,18 .

\section{Bisexual and heterosexual sexuality}

Due to space limitations, this article has focused relatively little attention on several other elements in the interviewees' sexual experience. As far as we know, this was the first study to include bisexual men in the context of HIV infection, based on their relationship with women, a widely discussed theme, but studied relatively little since the second decade of the epidemic, when the increase in HIV infection in women was attributed to the "bisexual bridge" 19. Seffner 20 already noted that most of the studies on bisexuality focused on relations with other men, i.e., almost never analyzing relations with women. Future studies should analyze the bisexuality of people living with HIV, including their relations with women.

Various authors have discussed how the propaganda about improvement in quality of life with ARV treatment encourages the legitimization of the norm known as "don't ask, don't tell" among HIV-positive homosexual men who assume (without asking) that the others also carry the virus, imagining that they have a low viral load, controlled by the medication 21,22 .

The proportion of HIV-negative male partners in our study was low $36.6 \%$ for the main partner and $25 \%$ for all the partners) when compared to a study in the United States 7 (58\%) in a homosexual and bisexual sample. Meanwhile, the proportion of HIV-negative female partners (44\%) among heterosexual interviewees in our study was similar to that found by the same authors that also investigated partners of HIV-positive men under treatment during the six months prior to the study. 
Other studies on serodiscordant couples 23,24 have discussed how HIV-negative partners feel "invisible", though they share the weight of the stigmatizing illness and struggle to keep the couple's sexual activity alive. This experience may explain the reported ambivalence of male and female partners vis-à-vis their probable seroconversion, denying the risk and wanting to share the seropositive status as proof of love and trust, an experience observed among the men in this study. In other words, disclosure alone does not guarantee protected sex 17 , and this is one of the reasons why many interviewees defended the inclusion of family members and partners (male and female) in the health services, a demand observed among HIV-positive women interviewed in a previous study 23 .

\section{Implications for care of men living with HIV}

The primary aim of this study was to describe the context in which self-disclosure of HIV-positive diagnosis has occurred and the barriers faced by male interviewees with their male and female sexual partners, thereby helping improve quality of care for their affective/sexual lives, which directly impacts the lives of their family members and partners. In this sense, we contend that encouraging users of health services to describe and debate their needs for psychosocial care, as we did, does foster understanding by health professionals and thus promotes equity and comprehensiveness in the services, which are basic principles of Brazilian Unified National Health System (SUS).

Although we found no differences between blacks and non-blacks, in contrast to a recent study in the United States 25 , a theme that merits another article, we found significant differences between heterosexual and homosexuals. Support for persons living with HIV to plan "processes of disclosure" to their partners should consider differences in inter-subjective contexts.

When holding the discussion groups in the group sessions follow up study with the interviewees, we confirmed the impression that heterosexual men feel less at ease with (or actually distrust) spaces for support, with which many of them did not feel comfortable with because they considered them a "homosexual space". However, we observed that these men benefited from sharing their personal experiences in group situations, just as much as women, who are included more often in this kind of initiative 23,26 . In the more in-depth reports in response to the open questions on their experiences with health services, approached dynamically in the group discussions, we confirmed the impor- tance of welcoming questions on sexuality and condom use and the usefulness of a professional approach that takes the protection of rights into account. Equally productive is comprehensive health promotion that protects the right to build a family and the right to sexuality and life in the community without discrimination, that is, a health service not limited to the management of HIV infection. Sharing experiences with other men in the same condition, as we observed, can also facilitate the progressive structuring of disclosure of seropositive status when and to whom they decide, a process that should allow better care for others and themselves, whereby affective and sexual life is experienced with greater tranquility.

Silva et al. 26 showed that professionals in SUS recognize that experience with group discussion expands the exclusive discussion of the condition as "virus carrier" to the context of daily life (and conjugality), overcoming the victimization discourse to force protagonists. In the setting of the above-mentioned study, the health professionals identified the central importance of "managing the stigma" associated with AIDS, a theme that emerges in the interviews and group discussions.

The notion of "disclosure", common in studies of the experience with homosexuality and with AIDS, reveals the process of stigmatization and the context of violation of rights for persons living with HIV 1,6,12. The issue is a secret that needs to be hidden, and the challenge is to remove the veil, "to disclose", and not simply "to tell", to talk about their condition with a viral infection. As some authors working with prevention have insisted 27 and analyses of the epidemic have indicated 28,29, the fight against stigma and discrimination, protection of human rights, safeguards for autonomy, dignity, and physical and mental well-being (and less stress) for persons living with HIV will definitely stimulate the control of the spread of the epidemic.

Importantly, as in our study, in countries that also have the privilege of access to treatment and where disclosure of HIV-positive status is not compulsory, persons that do not reveal their diagnosis manage to talk about prevention and incorporate consistent condom use, while persons that disclose sometimes have sex without condoms 5,17,24,30,31. Meanwhile, we confirmed that self-disclosure of HIV-positive status has not necessarily been associated with consistent condom use. In planning care for persons living with HIV, it is important to note that avoiding the stress resulting from non-disclosure, as other authors have already indicated, produces other obvious benefits $23,30,32,33$. For example, the social 
support resulting from disclosure diminishes the depression that follows diagnosis. In this sense, we observed a greater tendency to disclosure and higher adherence to condom use in men that discussed the issue at least once with health professionals and participated in support groups 5,17. Furthermore, the proportion of protected sex has been positively associated with conversations on safe sex with sexual partners, and not only with disclosure 17,24,30,31.

As we have discussed elsewhere, it is not up to professionals to determine how people will behave or what decisions they will make in their affective, family, reproductive, or sexual lives, or particularly in relation to disclosure of their serostatus. It is up to the state 29 and health workers to implement the principles of the SUS, and at least to tackle the challenge of guaranteeing everyone's right to sexual and reproductive health with quality, in order for their decisions in daily life to be made after being adequately informed and their difficulties understood, rather than being reduced to "HIV carriers", but supported as "persons living with HIV”.

\section{Resumo}

Este estudo investigou a revelação da soropositividade para parceiro/as sexuais por homens, hetero e bissexuais, usuários de serviços especializados no cuidado ao HIVIAIDS. Por meio de 250 entrevistas individuais e grupo focal descrevemos a revelação segundo características das parcerias e discutimos as dificuldades para manter ou estabelecer novas relações afetivo-sexuais e com o sexo protegido. Observamos que o temor à rejeição provoca isolamento e sofrimento e dificultava a revelação para parceiralos atuais ou futuro/as. Revelar requer confiança e foi mais frequente para parceiral os fixalos, para soropositivalos, para mulheres, e menos frequente para parceirolas pagos por "programa". Heterossexuais revelavam mais. A maioria usava preservativos consistentemente, embora menos frequentemente com parceiros soropositivos. Para melhorar o cuidado integral de homens soropositivos, sugere-se a "gestão do estigma", atividades em grupo e abordagens baseadas em direitos humanos que capacitem profissionais para o cuidado da vida sexual-afetiva, da revelação e ao apoio ao viver com HIV.

Sexualidade; HIV; Síndrome de Imunodeficiência Adquirida

\section{Contributors}

V. Paiva participated in the project's coordination, fieldwork, analysis, and writing of the article. A. C. Segurado and E. M. V. Filipe collaborated in the elaboration of the project, fieldwork coordination, data analysis, and writing of the article.

\section{Acknowledgments}

The authors wish to acknowledge the initial support of the University of California-San Francisco and Norman Hearst for the academic and financial support for the project and the CNPq for its support in the form of productivity scholarships. The comments and direct participation in data collection by colleagues from the Casa da AIDS (HC-FMUSP), CRT-AIDS/SP, and NEPAIDSUSP, as always, were important in the work process that led to this article. 


\section{References}

1. Valle CG. Identidades, doença e organização social: um estudo das "pessoas vivendo com HIV e AIDS”. Horizontes Antropológicos 2002; 8:179-210.

2. Freitas MRI, Gir E, Furegato ARF. Sexualidade do portador do vírus da imunodeficiência humana (HIV): um estudo com base na teoria da crise. Rev Latinoam Enferm 2002; 10:70-6.

3. Reis RK, Gir E. Dificuldades enfrentadas pelos parceiros sorodiscordantes ao HIV na manutenção do sexo seguro. Rev Latinoam Enferm 2005; 13:32-7.

4. Silveira MF, Santos I. Impacto de intervenções no uso de preservativos em portadores do HIV. Rev Saúde Pública 2005; 39:296-304.

5. Sullivan KM. Male self-disclosure of HIV-positive serostatus to sex partners: a review of the literature. J Assoc Nurses AIDS Care 2005; 16:33-47.

6. Garrido PB, Paiva V, Nascimento V, Souza JB, Santos N. AIDS, estigma e desemprego: implicações para os serviços de saúde. Rev Saúde Pública 2007; 41:72-9.

7. Ciccarone DH, Kanouse DE, Collins RL, Miu A, Chen JL, Morton SC, et al. Sex without disclosure of positive HIV serostatus in a US probability sample of persons receiving medical care for HIV infection. Am J Public Health 2003; 93:949-54.

8. Klitzman R, Bayer R. Mortal secrets: truth and lies in the age of AIDS. Baltimore: John Hopkins University Press; 2003.

9. Marques HHS, Silva NG, Gutierrez PL, Lacerda R, Ayres JRCM, DellaNegra M, et al. A revelação do diagnóstico na perspectiva dos adolescentes vivendo com HIV/AIDS e seus pais e cuidadores. Cad Saúde Pública 2006; 22:619-29.

10. Ferreira FC, Nichiata LYI. Mulheres vivendo com AIDS e os profissionais do Programa Saúde da Família: revelando o diagnóstico. Rev Esc Enferm USP 2008; 42:483-9.

11. Filipe EMV, Batistella E, Pini A, Santos N, Paiva V, Segurado A, et al. Sexual orientation, use of drugs and risk perception among HIV-positive men in São Paulo, Brazil. Int J STD AIDS 2005; 16:56-60.

12. Paiva V, Filipe EV, Santos N, Lima T, Segurado AAC. The right to love: the desire for parenthood among men living with HIV. Reprod Health Matters 2003; 11:91-100.

13. Segurado AC, Batistela E, Nascimento V, Braga PE, Filipe E, Santos N, et al. Sexual abuse, victimization and perpetration in a cohort of men living with HIV/AIDS who have sex with women from São Paulo, Brazil. AIDS Care 2008; 20:15-20.

14. Lopes F. Para além da barreira dos números: desigualdades raciais e saúde. Cad Saúde Pública 2005; 21:1595-601.

15. Polistuchck L. Práticas e significados da sexualidade de homens que fazem sexo com mulheres e que vivem com HIV/AIDS [Specialization Course Monograph]. São Paulo: Casa da AIDS, Faculdade de Medicina, Universidade de São Paulo; 2006.

16. Villarinho L, Bezerra I, Lacerda R, Latorre MRDO, Paiva V, Stall R, et al. Caminhoneiros de rota curta e sua vulnerabilidade ao HIV. Rev Saúde Pública 2002; 36:61-7.
17. Relf M, Bishop T, Lachat M, Schiavone D, Pawlowski L, Bialko M, et al. A qualitative analysis of partner selection, HIV serostatus disclosure, and sexual behaviors among HIV-positive urban men. AIDS Educ Prev 2009; 21:280-97.

18. Marks G, Crepaz N. HIV-positive men's sexual practices in the context of self-disclosure of HIV status. J Acquir Immune Defic Syndr 2001; 27:79-85.

19. Guimarães CD. Mulheres, homens e AIDS: o visível e o invisível. In: Parker R, Bastos C, Galvão, J, Pedrosa JS, organizadores. A AIDS no Brasil. Rio de Janeiro: Associação Brasileira Interdisciplinar de AIDS/Editora Relume-Dumará; 1994. p. 217-31.

20. Seffner F. Derivas da maculinidade: representação, identidade e diferença no âmbito da masculinidade bissexual [Doctoral Dissertation]. Porto Alegre: Programa de Pós-graduação em Educação, Universidade Federal do Rio Grande do Sul; 2003.

21. Sheon N, Crosby GM. Ambivalent tales of disclosure. Soc Sci Med 2004; 58:2105-18.

22. Gorbach PM, Galea JT, Amani B, Shin A, Celum C, Kerndt P, et al. Don't ask, don't tell: patterns of HIV disclosure among HIV positive men who have sex with men with recent STI practising high risk behaviour in Los Angeles and Seattle. Sex Transm Infect 2004; 80:512-7.

23. Tunala L, Paiva V, Filipe EMV, Santos T, Santos N, Hearst N. Fatores psicossociais que dificultam a adesão das mulheres portadoras do HIV aos cuidados de saúde. In: Teixeira P, Paiva V, Shimma E, organizadores. Tá dificil de engolir? São Paulo: Núcleo de Estudos para Prevenção da AIDS, Centro de Referência e Treinamento em DST-AIDS; 2000. p. 79-114.

24. van der Straten A, Vernon KA, Knight KR, Gómez CA, Padian NS. Managing HIV among serodiscordant heterosexual couples: serostatus, stigma and sex. AIDS Care 1998; 10:533-48.

25. Bird JD, Fingerhut DD, McKirnan DJ. Ethnic differences in HIV-disclosure and sexual risk. AIDS Care 2011; 24:1-5.

26. Silva NEK, Ayres JRCM. Estratégias para comunicação de diagnóstico de HIV a parceiros sexuais e práticas de saúde. Cad Saúde Pública 2009; 25:1797-806

27. Padian NS. Commentary. Sex Transm Infect 2006; 82:119-20.

28. Berkman A, Garcia J, Munoz-Laboy M, Paiva VSF, Parker R. A critical analysis of the Brazilian response to HIV/AIDS: lessons for controlling and mitigating the epidemic in developing countries. Am J Public Health 2005; 95:1162-72.

29. Gruskin S, Tarantola D. Universal access to HIV prevention, treatment and care: assessing the inclusion of human rights in international and national strategic plans. AIDS 2008; 22 Suppl 2: S123-32.

30. Marks G, Richardson JL, Crepaz N, Stoyanoff S, Milam J, Kemper C, et al. Are HIV care providers talking with patients about safer sex and disclosure? A multi-clinic assessment. AIDS 2002; 16:1953-7. 
31. Crepaz N, Marks G. Towards an understanding of sexual risk behavior in people living with HIV: a review of social, psychological and medical findings. AIDS 2002; 16:135-49.

32. Kalichman SC, DiMarco M, Austin J, Luke W, DiFonzo K. Stress, social support, and HIV status disclosure to family and friends among HIV-positive men and women. J Behav Med 2003; 26:315-32.
33. Zea MC, Reisen CA, Poppen PJ, Bianchi FT, Echeverry JJ. Disclosure of HIV status and psychological well-being among Latino gay and bisexual men. AIDS Behav 2005; 9:15-26.

Submitted on 14/May/2009

Final version resubmitted on 05/Mar/2011

Approved on 18/Mar/2011 